\title{
The Persistence and Transfer of Learning in Industrial Settings
}

\author{
Linda Argote; Sara L. Beckman; Dennis Epple \\ Management Science, Vol. 36, No. 2. (Feb., 1990), pp. 140-154.
}

Stable URL:

http://links.jstor.org/sici?sici=0025-1909\%28199002\%2936\%3A2\%3C140\%3ATPATOL\%3E2.0.CO\%3B2-0

Management Science is currently published by INFORMS.

Your use of the JSTOR archive indicates your acceptance of JSTOR's Terms and Conditions of Use, available at

http://www.jstor.org/about/terms.html. JSTOR's Terms and Conditions of Use provides, in part, that unless you have obtained prior permission, you may not download an entire issue of a journal or multiple copies of articles, and you may use content in the JSTOR archive only for your personal, non-commercial use.

Please contact the publisher regarding any further use of this work. Publisher contact information may be obtained at http://www.jstor.org/journals/informs.html.

Each copy of any part of a JSTOR transmission must contain the same copyright notice that appears on the screen or printed page of such transmission.

The JSTOR Archive is a trusted digital repository providing for long-term preservation and access to leading academic journals and scholarly literature from around the world. The Archive is supported by libraries, scholarly societies, publishers, and foundations. It is an initiative of JSTOR, a not-for-profit organization with a mission to help the scholarly community take advantage of advances in technology. For more information regarding JSTOR, please contact support@ jstor.org. 


\title{
THE PERSISTENCE AND TRANSFER OF LEARNING IN INDUSTRIAL SETTINGS*
}

\author{
LINDA ARGOTE, SARA L. BECKMAN AND DENNIS EPPLE \\ Graduate School of Industrial Administration, Carnegie Mellon University, \\ Pittsburgh, Pennsylvania 15213 \\ University of California, Berkeley, California 94720 \\ Graduate School of Industrial Administration, Carnegie Mellon University, \\ Pittsburgh, Pennsylvania 15213
}

\begin{abstract}
The persistence of learning within organizations and the transfer of learning across organizations are examined on data collected from multiple organizations. Results indicate that knowledge acquired through production depreciates rapidly. The conventional measure of learning, cumulative output, significantly overstates the persistence of learning. There is some evidence that learning transfers across organizations: organizations beginning production later are more productive than those with early start dates. Once organizations begin production, however, they do not appear to benefit from learning in other organizations. The implications of the results for a theory of organizational learning are discussed. Managerial implications are described.

(ORGANIZATIONAL LEARNING; LEARNING CURVES; PRODUCTIVITY; TECHNOLOGY TRANSFER)
\end{abstract}

The presence of a learning curve has been documented in many industries. Yet we know little about why learning occurs. For example, is learning attributable to accumulating experience of production workers or management, to increasing sophistication of capital equipment, or to improved coordination of the production process? Similarly, there is little evidence regarding the extent to which learning is transferred across organizations. Further, the presumption that learning is associated with cumulative output implies that learning persists through time, but there is little evidence about the extent to which learning persists. Our goals in this paper are to examine empirically the persistence and transfer of learning in organizations.

These issues are clearly important. The dynamics of learning are important issues for organizations in pricing, hiring employees, planning production schedules and anticipating the behavior of rivals. The learning curve has been used as a base for predicting the cost of replacement labor (Kilbridge 1962), for gauging the effects of training (Levy 1965), for determining cost savings from overseas production (Jucker 1977), for making marketing decisions, and for setting manufacturing strategy (Hayes and Wheelwright 1984). The rate and transfer of learning are also central concerns for antitrust policy (Spence 1981).

In the next section, we review previous work on the learning curve and develop the research questions for the current study. Following this, we discuss the methods and data used in the analysis and present results on the persistence and transfer of learning. We then apply the results to Lockheed's production of the L-1011 (cf. Wall Street Journal, $1980 \mathrm{a}$, p. 12). The paper concludes with an interpretation of the results and a discussion of their implications for theory and practice.

\section{Overview of Previous Research}

Early investigations of learning focused on the behavior of individual subjects. These investigations revealed that the time required to perform a task declined at a decreasing

* Accepted by Richard M. Burton; received July 31, 1987. This paper has been with the authors 7 months for 2 revisions. 
rate as experience with the task increased (Thorndike 1898; Thurstone 1919; Graham and Gagné 1940). The term "learning curve" was coined to denote this characteristic learning pattern.

More recently, researchers interested in the behavior of individuals have focused on the process through which individuals learn and modify their problem-solving strategies (Anzai and Simon 1979). Newell and Rosenbloom (1981) and Mazur and Hastie (1978) provide recent reviews of research on learning by individual subjects. Examining the performance of individuals in organizations, Kelsey et al. (1984) found that as the experience of surgeons increased, their success rates at angioplasty procedures increased. The performance of small groups also fits the characteristic learning-curve pattern (Leavitt 1951; Guetzkow and Simon 1954; Baloff 1967).

A pattern similar to that observed for individuals and small groups has also been found at organizational (e.g., Wright 1936; Hirsch 1956; Alchian 1963) and industry (e.g., Sheshinski 1967) levels. At these levels of analysis, the phenomenon, or close variants of it, is alternatively referred to as a learning curve, an experience curve, or learning by doing. At the organizational level of analysis, the first published documentation of the learning curve is provided by Wright (1936), who observed that unit labor inputs in airframe production declined with cumulative output. Preston and Keachie (1964) found that unit total costs as well as unit labor costs declined with cumulative output. They also demonstrated a dependence of unit labor costs on both the rate of output and cumulative output.

Rapping (1965) provided particularly convincing evidence of learning by doing at the organizational level. Rapping employed data from several organizations producing the same product-emergency shipyards that produced the Liberty Ship during World War II. Rapping demonstrated that the observed increase in the rate of output with cumulative production was not due simply to increased inputs of labor and capital, or to increasing exploitation of economies of scale, or to the passage of time.

Other empirical work on the learning curve in organizations has focused on investigating whether learning by doing occurs in other industries and on investigating the functional form of the learning curve (Yelle 1979). Indeed in a recent paper, Lieberman (1984) concluded that while the learning curve has achieved widespread practical acceptance, little is known about the precise nature of the learning process. Similarly, Yelle (1979) indicated that identifying factors favoring an accelerated rate of learning is a promising area for future research. Joskow and Rose (1985) suggested that examining the persistence of learning in organizations is also an important area for additional research.

\section{The Research Questions}

In this research, we examine whether learning persists within organizations and whether it transfers across organizations. Concerning persistence, theoretical research and simulation results have pointed out the implications of forgetting for planning and scheduling (Sule 1983; Smunt and Morton 1985; Smunt 1987). In addition, there is much evidence in the psychological literature that if the practicing of a task by an individual is interrupted, forgetting occurs (Ebbinghaus 1885). While interference from other tasks causes forgetting, forgetting occurs when performance is delayed even if there is no interference (Anderson 1985; Wickelgren 1976). When performance is resumed, it is typically inferior to when it was interrupted but superior to when it began initially (e.g., see Kolers 1976).

A small number of empirical studies have examined the effects of an interruption in production on learning in organizations. For example, Hirsch (1952) and Baloff (1970) found that when performance was resumed after an interruption at a firm, it was lower than the level achieved prior to the interruption. Batchelder, Boren, Campbell, Dei Rossi and Large (1969) presented an example of a "scallop" learning curve in which manu- 
facturing costs rise abruptly and then decline. According to Batchelder et al., the "scallop" is generally caused by a major interruption in the production process.

Even though there is some evidence that "forgetting" may occur in organizations, the assumption is often made in the organizational learning curve literature that learning is cumulative-that it persists through time and does not evidence depreciation. In fact, most empirical analyses of learning in organizations are based on this assumption and hence use cumulative output as the measure of learning (e.g., see the many studies cited in Yelle's review). Futher empirical investigation of persistence in industrial settings is clearly needed.

The current study examines the persistence of learning in multiple organizations. We develop a procedure for estimating the amount of depreciation that occurs while controlling for inputs of labor and capital. Controlling for input levels is particularly important in field research on organizations because it is important to demonstrate that any decrease observed in productivity after an interruption or change in the rate of output is not due to changes in these factors.

We also examine the transfer of learning-whether production experience acquired in one organization transfers to another. ${ }^{1}$ Concerning transfer, Zimmerman (1982) found evidence of transfer of learning in the construction of nuclear power plants. Zimmerman noted, however, that firm-specific learning was more significant than nonfirm specific learning. Joskow and Rose (1985) did not find statistically significant evidence of transfer of industry experience in the construction of coal-burning generating units.

The organizations in our data set appear to have promoted transfer of knowledge. The organizations produced the same product and its design was standardized (Lane 1951). A central agency was responsible for purchasing, approving plant layout and technology, and supervising construction. The central agency also had engineers, auditors, and inspectors stationed at each organization. Thus, mechanisms for the transfer of knowledge existed. In the current study, we examine empirically whether transfer occurred.

\section{Method}

\section{Sources of Data}

The data set is based on data from the construction of Liberty Ships during World War II (Fisher 1949). ${ }^{2}$ The Liberty Ship was built in 16 different shipyards. On average, two months were required to build a Liberty Ship. A large number were produced2708. A standard design was adopted and produced with minor variation in all of the yards. Parts were standardized, procured by a central authority, and distributed to the yards (Lane 1951).

All of the yards producing the Liberty Ship began production during 1941 or 1942. These were new yards, known as Emergency Shipyards, constructed under the authority of the U.S. Maritime Commission. The Liberty Ship was the first ship to be produced in any of the yards, and it was the only ship produced by the yards during a significant part of the war. The vast majority of workers employed in the Emergency Shipyards had no prior experience in shipbuilding (Fisher 1949).

Hence, the data are from a virtually unique situation. A large number of a single homogeneous product were produced from homogeneous raw materials in a large number of organizations with workers who shared a common level of prior industry experience.

\footnotetext{
${ }^{1}$ The psychological research on transfer typically examines how performing one task affects the performance of another task by the same individual. This research is not particularly relevant for examining transfer across organizations in the current study since there was virtually no movement of individual production workers across them.

${ }^{2}$ Rapping (1965) also used these data in his investigation of whether learning occurred in the Liberty Ship program. The current study uses the data set to examine the persistence and transfer of learning.
} 
These features of the Liberty Ship program come as near as one is likely to encounter in the field to controlling for a host of important factors (e.g., prior experience of workers, product characteristics, input characteristics) that are difficult to control for statistically in most production environments.

Fortunately, the yards in the sample began production at different times, produced at very different scales of operation, and experienced different rates of labor turnover. Therefore, these data allow us to study the persistence of learning within shipyards and the transfer of learning across shipyards.

\section{Key Variables}

The symbols we use throughout the paper and the variables they represent are listed below and described in greater detail in the text that follows.

\begin{tabular}{ll}
\multicolumn{1}{c}{ Symbol } & \multicolumn{1}{c}{ Variable } \\
$t$ & Calendar time in months; $t=1$ in January 1941 \\
$q_{i t}$ & Tonnage (in thousands) produced in yard $i$ in month $t$ \\
$H_{i t}$ & Labor hours (in hundreds) in yard $i$ in month $t$ \\
$W_{i t}$ & Shipways used in yard $i$ in month $t$ \\
$Q_{i t}=\sum_{s=0}^{t} q_{i s}$ & Cumulative output in yard $i$ through month $t$ \\
$A_{t}=\sum_{i=1}^{13} Q_{i t}$ & Aggregate cumulative output through month $t$ \\
$K_{i t}$ & Knowledge acquired in yard $i$ through month $t$ \\
$A K_{t}=\sum_{i=1}^{13} K_{i t}$ & Aggregate knowledge acquired through month $t$ \\
$S_{i}$ & Month production started in yard $i$ \\
$\operatorname{Hire}_{i t}$ & Number of new hires per hundred employees in yard $i$ in month $t$ \\
$\operatorname{Sep}_{i t}$ & Number of separations per hundred employees in yard $i$ in month $t$
\end{tabular}

Tonnage produced per month refers to the weight of all vessels or portions of vessels produced during a month. Womer (1984) demonstrated that erroneous inferences may be drawn from empirical analyses of learning if the measure of output is based on units finished in a given month, and the period of production exceeds a month. This problem does not arise in our investigation since output is based on tonnage constructed in a given month.

Shipways are the structures upon which the ships were built. Following Rapping (1965), shipways in use is our measure of capital inputs. In our analysis, data from 13 of the 16 yards that produced Liberty Ships are used. Data on one or more variables were missing for the other yards.

\section{Analysis Plan}

We estimated models in which output depends on the inputs of labor (labor hours), capital (shipways), and on other variables. ${ }^{3}$ Specifically, we estimated production functions of the following form:

$$
\operatorname{Ln} q_{i t}=a_{0}+\sum_{i=2}^{13} a_{i} D_{i}+\alpha \operatorname{Ln} H_{i t}+\beta \operatorname{Ln} W_{i t}+\gamma \operatorname{Ln} K_{i t-1}+\delta^{\prime} Z_{i t}+u_{i t}
$$

where

$$
\begin{aligned}
K_{i t} & =\lambda K_{i t-1}+q_{i t} \quad \text { and } \\
u_{i t} & =\rho_{1} u_{i t-1}+\rho_{2} u_{i t-2}+\rho_{3} u_{i t-3}+\epsilon_{i t} .
\end{aligned}
$$

\footnotetext{
${ }^{3}$ Data on output are available from the beginning of production in each yard, but observations on other variables typically are unavailable until the yard has been operating for a month or more. Hence, the first month of production never appears in our sample. Consequently, $K_{i t-1}$ is always greater than zero and $\operatorname{Ln} K_{i t-1}$ is always defined.
} 
In equation (1), the $D_{i}$ are dummy variables for the shipyards. These dummy variables are included to capture unmeasured yard-specific factors such as land that are relatively constant through time. Variable $K_{i t}$ is the stock of knowledge accumulated by yard $i$ at date $t$. As equation (2) indicates, this stock increases with output. Equation (2) allows for the possibility that the stock of knowledge depreciates over time by inclusion of the parameter $\lambda$ which must lie in the interval $[0,1]$. If $\lambda=1$, the accumulated stock of knowledge is simply equal to lagged cumulative output, the conventional measure of learning. By estimating $\lambda$, we obtain an estimate of the persistence of learning. As equation (1) indicates, knowledge acquired through the end of the preceding month, $K_{i t-1}$, appears in the production function for month $t$. Thus, past but not current output appears on the right-hand side of equation (1).

The vector $Z_{i t}$ in equation (1) varies from regression to regression and represents other variables that may influence productivity. The error $u_{i t}$ is assumed to be serially correlated as shown in equation (3). ${ }^{4}$ The choice of a third-order autoregressive error is a result of our analysis of the data and is explained shortly.

The monthly data have two limitations. First, the number of shipways in use by a shipyard is reported on an annual, not a monthly basis. Hence, in our analysis, we set the number of shipways in use in each month of the year for a given yard equal to the annual average for that yard. Second, monthly production is reported as output per shipway per month, not output per month. Hence, to calculate output per month, we multiplied output per shipway per month by the average number of shipways in use per year. The annual data do not have these limitations. We performed comparable analyses with the annual data and found similar results. Hence the limitations of the monthly data do not appear to be serious. Key findings from our analysis of the annual data are also presented.

Womer (1979) emphasized the importance of integrating the neoclassical production function and learning by doing. Because our data are from several organizations that differed significantly in scale of operation, we are able to undertake this integration successfully. By controlling for inputs of labor and capital, we are able to separate increases in productivity due to learning from increases in productivity due to increasing exploitation of economies of scale. In addition, calendar time is controlled for to separate the effect of technical progress associated with the passage of time from productivity improvements associated with increasing cumulative output.

\section{Results}

We first discuss results concerning the persistence and transfer of learning. Other potential explanations for our findings are then investigated including adjustment costs, choice of functional form, method of estimation, and economies of scale.

\section{The Persistence of Learning}

Results on persistence are presented in Table $1 .{ }^{5}$ The models were estimated by maximum likelihood. ${ }^{6}$ The maximum likelihood estimate of $\lambda$ for the model shown in Column

\footnotetext{
${ }^{4}$ The error term $\epsilon_{i t}$ in equation (3) is assumed to be serially uncorrelated and uncorrelated (in large samples) with all variables other than $u_{i t}$ on the right-hand side of equation (1). Furthermore, the $\epsilon_{i t}$ are assumed to be mutually uncorrelated. The serial correlation coefficients are assumed to be the same across all shipyards.

${ }^{5}$ The coefficients of the yard-specific dummy variables are not of particular interest so are not reported. A joint test of the null hypothesis that there are no yard-specific effects is rejected at a very high significance level $(p<0.001)$, so important yard-specific effects appear to be present. Yard-specific dummy variables are included in all analyses, except where otherwise indicated.

${ }^{6}$ Estimation is done using the following search procedure. Values of $\lambda$ in the interval $[0,1]$ are chosen. With $\lambda$ fixed, the remaining parameters are readily estimated by standard procedures for estimating regression models with autocorrelated errors. Hence, for each chosen value of $\lambda$, the remaining parameters are estimated. We
} 
TABLE 1

Results Concerning the Persistence of Learning*

\begin{tabular}{|c|c|c|c|c|c|}
\hline & (1) & (2) & (3) & (4) & (5) \\
\hline Constant & $\begin{array}{l}-3.91 \\
(12.72)\end{array}$ & $\begin{array}{l}-3.74 \\
(9.73)\end{array}$ & $\begin{array}{l}-3.85 \\
(11.75)\end{array}$ & $\begin{array}{l}-3.83 \\
(11.87)\end{array}$ & $\begin{array}{l}-3.52 \\
(10.95)\end{array}$ \\
\hline $\begin{array}{l}\text { Labor hours } \\
\quad\left(\operatorname{Ln} H_{i t}\right)\end{array}$ & $\begin{array}{l}0.16 \\
(5.14)\end{array}$ & $\begin{array}{l}0.18 \\
(5.18)\end{array}$ & $\begin{array}{l}0.16 \\
(4.60)\end{array}$ & $\begin{array}{l}0.15 \\
(4.38)\end{array}$ & $\begin{array}{l}0.14 \\
(4.09)\end{array}$ \\
\hline $\begin{array}{l}\text { Shipways } \\
\left(\operatorname{Ln} W_{i t}\right)\end{array}$ & $\begin{array}{l}1.15 \\
(21.83)\end{array}$ & $\begin{array}{l}1.08 \\
(21.02)\end{array}$ & $\begin{array}{l}1.15 \\
(21.77)\end{array}$ & $\begin{array}{l}1.13 \\
(21.84)\end{array}$ & $\begin{array}{l}1.12 \\
(19.38)\end{array}$ \\
\hline $\begin{array}{l}\text { Knowledge } \\
\quad\left(\operatorname{Ln} K_{i t-1}\right)\end{array}$ & $\begin{array}{l}0.65 \\
(31.42)\end{array}$ & & $\begin{array}{l}0.71 \\
(9.54)\end{array}$ & $\begin{array}{l}0.71 \\
(17.82)\end{array}$ & $\begin{array}{l}0.67 \\
(29.96)\end{array}$ \\
\hline$\lambda$ & $0.75^{\mathrm{a}}$ & & $0.75^{\mathrm{a}}$ & 0.85 & $0.70^{\mathrm{a}}$ \\
\hline $\begin{array}{l}\text { Cumulative output } \\
\quad\left(\operatorname{Ln} Q_{i t-1}\right)\end{array}$ & & $\begin{array}{l}0.44 \\
(15.74)\end{array}$ & $\begin{array}{l}-0.04 \\
(0.72)\end{array}$ & & \\
\hline $\begin{array}{l}\text { Calendar time } \\
\quad(t)\end{array}$ & & & & $\begin{array}{l}-0.01 \\
(3.33)\end{array}$ & \\
\hline $\begin{array}{l}\text { New hires } \\
\quad\left(\text { Ln Hire }{ }_{i t}\right)\end{array}$ & & & & & $\begin{array}{l}0.003 \\
(0.22)\end{array}$ \\
\hline $\begin{array}{l}\text { Separations } \\
\quad\left(\operatorname{Ln~Sep}_{i t}\right)\end{array}$ & & & & & $\begin{array}{l}-0.019 \\
(1.09)\end{array}$ \\
\hline$R^{2}$ & 0.9911 & 0.9900 & 0.9912 & 0.9912 & 0.9905 \\
\hline $\operatorname{Ln} L$ & 379.047 & 358.254 & 379.321 & 380.463 & 375.680 \\
\hline$N$ & 337 & 337 & 337 & 337 & 327 \\
\hline
\end{tabular}

* Unstandardized coefficients are reported, with associated $t$-statistics shown in parentheses. $\operatorname{Ln} L$ is the natural logarithm of the likelihood function.

${ }^{\text {a }}$ Significantly different from one $(p<0.000001)$.

(1) of Table 1 is $0.75 .^{7}$ The estimation procedure does not yield a standard error for $\lambda .^{8}$ However, using the distribution of the likelihood ratio, we have determined that a $93 \%$ confidence interval for $\lambda$ is roughly $(0.65,0.85)$. The hypothesis $\lambda=1.0$ is very strongly rejected. Hence, the conventional measure of learning, cumulative output, significantly overstates the persistence of learning.

began with a search over values of $\lambda$ at increments of 0.05 in the interval $[0,1]$ to identify the subinterval in which the function reaches a maximum and then located the maximum by searching that subinterval at increments of $\lambda$ of 0.01 . The maximum likelihood estimates for the overall model are then the value of $\lambda$ and the values of the associated coefficients which yield the largest value of the likelihood function. This procedure is equivalent to nonlinear search procedures that vary all parameters simultaneously, but is computationally easier to implement. This scanning procedure for maximum likelihood estimation is discussed in Goldfeld and Quandt (1972) and developed in greater detail by Dhrymes (1966).

${ }^{7}$ The serial correlation coefficients are not of particular interest so are not reported. Third-order serial correlation coefficients all reached at least the 0.05 level of significance. This is not surprising since production of a ship required an average of two months, and longer periods were required early in production. Estimates of the other parameters are not sensitive to the order of serial correlation. For example, with either first or second-order autocorrelation, the maximum likelihood estimate of $\lambda$ for the model in Column (1) of Table 1 is 0.80 . Since autocorrelation coefficients up to third-order are significant, we adopted the third-order specification for the remaining analyses.

${ }^{8}$ The standard errors of the remaining coefficients are computed treating $\lambda$ as a known parameter. This may result in some understatement of the standard errors of the coefficients and a corresponding overstatement of the $t$-statistics. Therefore, all conclusions regarding significance of alternative measures of learning are based on likelihood ratio tests. 
Indeed, these results indicate a rapid rate of depreciation. A value of $\lambda=0.75 \mathrm{implies}$ that, from a stock of knowledge available at the beginning of a year, only $3.2 \%\left(0.75^{12}\right)$ would remain one year later. Thus, if the stock of knowledge is not replenished by continuing production, it depreciates rapidly. Even with a value of $\lambda$ as high as 0.90 , only $28 \%$ of a given stock of knowlege would remain one year later.

The contrast of Columns (1) and (2) of Table 1 provides further evidence that learning depreciates and that our knowledge variable is a better measure of learning than the conventional measure, lagged cumulative output. Column (1) is identical to Column (2) except that Column (1) includes the knowledge variable whereas Column (2) includes the conventional measure of learning. The log of the likelihood function in Column (1) is significantly greater than the log of the likelihood function in Column (2), $\chi^{2}=41.59$, $d f=1, p<0.000001$.

Results presented in Column (3) of Table 1 show the effect of including the conventional measure of learning, lagged cumulative output, and the knowledge variable in the same model. When lagged cumulative output is included, the value of $\lambda$ that maximizes the likelihood function is 0.75 , as in Column (1). Moreover, cumulative lagged output has a small, statistically insignificant coefficient. This is further evidence that the knowledge variable captures the effects of learning better than cumulative output does.

In Column (4) calendar time is introduced to capture the possibility that technical change associated with the passage of time rather than learning is responsible for productivity improvements in shipbuilding. The negative coefficient for the time variable indicates that this is not the case. Further results concerning the time variable are discussed later in the section on more general production functions.

The depreciation of knowledge could be related to turnover. Therefore, labor turnover is included in the model shown in Column (5) of Table 1. There, the rate of new hires and the rate of separations were included as explanatory variables. ${ }^{9}$ As can be seen from Column (5), these variables together do not contribute significantly to explaining changes in productivity. Additional analyses (available on request) revealed that neither variable makes a significant contribution when included separately. The estimate of the depreciation parameter in Column (5), $\lambda=0.70$, indicates that knowledge depreciates rapidly when the effects of labor turnover are controlled for.

The results presented in Table 1 indicate that learning is acquired through experience in production. They also indicate that learning does not persist-knowledge acquired through production depreciates rapidly. ${ }^{10}$ With the exception of the model that included calendar time, estimates of $\lambda$, the depreciation parameter, are all significantly less than one.

\section{Transfer of Learning}

Results on the transfer of learning are reported in Table 2. If knowledge acquired through production transfers across yards, the coefficient of $A K_{t-1}$, the knowledge variable

\footnotetext{
${ }^{9}$ This run has fewer observations than previous runs because of missing data for rates of hires and separations. Hence, the likelihood function values for this equation cannot be compared to those for other equations in Table 1.

${ }^{10}$ A referee expressed the concern that our persistence finding might possibly be an artifact of estimating monthly output by multiplying monthly production per shipway by an annual measure of shipways in use. This is a valid concern that, ideally, we would like to address by use of a direct measure of monthly production. Since we were unable to obtain such a measure of monthly production, we investigated the persistence issue using annual data (for which all variables are measured for the same time unit). We contrasted the explanatory power of lagged output (i.e., output in the previous year) with that of lagged cumulative output. Specifically, we estimated a model that included labor hours, shipways, lagged cumulative output, lagged output, and time. The coefficient of lagged output was positive and significant, $t=2.09, d f=40, p<0.05$, while the coefficient of lagged cumulative output was negative and insignificant. These results indicate that recent experience is a significant predictor of learning while cumulative experience is not. Thus, the annual results support those obtained for the monthly data.
} 
TABLE 2

Results Concerning the Transfer of Learning*

\begin{tabular}{|c|c|c|c|c|}
\hline & (1) & (2) & (3) & (4) \\
\hline Constant & $\begin{array}{l}-3.79 \\
(12.73)\end{array}$ & $\begin{array}{l}-3.65 \\
(10.03)\end{array}$ & $\begin{array}{l}-3.37 \\
(9.52)\end{array}$ & $\begin{array}{l}-3.40 \\
(10.04)\end{array}$ \\
\hline $\begin{array}{l}\text { Labor hours } \\
\left.\text { (Ln } H_{i t}\right)\end{array}$ & $\begin{array}{l}0.18 \\
(5.42)\end{array}$ & $\begin{array}{l}0.13 \\
(4.10)\end{array}$ & $\begin{array}{l}0.13 \\
(4.00)\end{array}$ & $\begin{array}{l}0.14 \\
(3.95)\end{array}$ \\
\hline $\begin{array}{l}\text { Shipways } \\
\quad\left(\operatorname{Ln} W_{i t}\right)\end{array}$ & $\begin{array}{l}1.16 \\
(21.64)\end{array}$ & $\begin{array}{l}1.10 \\
(22.03)\end{array}$ & $\begin{array}{l}1.08 \\
(22.11)\end{array}$ & $\begin{array}{l}1.11 \\
(19.34)\end{array}$ \\
\hline $\begin{array}{l}\text { Knowledge } \\
\quad\left(\operatorname{Ln} K_{i t-1}\right)\end{array}$ & $\begin{array}{l}0.70 \\
(29.47)\end{array}$ & $\begin{array}{l}0.58 \\
(18.80)\end{array}$ & $\begin{array}{l}0.56 \\
(16.72)\end{array}$ & $\begin{array}{l}0.76 \\
(15.31)\end{array}$ \\
\hline$\lambda$ & $0.70^{\mathrm{a}}$ & $0.85^{b}$ & $0.88^{\mathrm{b}}$ & $0.76^{\mathrm{c}}$ \\
\hline $\begin{array}{l}\text { Aggregate knowledge } \\
\quad\left(\operatorname{Ln} A K_{t-1}\right)\end{array}$ & $\begin{array}{l}-0.06 \\
(2.45)\end{array}$ & & & $\begin{array}{l}-0.06 \\
(1.66)\end{array}$ \\
\hline $\begin{array}{l}\text { Start date } \\
\quad\left(S_{i}\right)\end{array}$ & & $\begin{array}{l}0.027 \\
(5.23)\end{array}$ & & \\
\hline $\begin{array}{l}\text { Calendar time } \\
\quad(t)\end{array}$ & & & & $\begin{array}{l}-0.007 \\
(2.34)\end{array}$ \\
\hline $\begin{array}{l}\text { Aggregate cumulative output } \\
\text { prior to start date } \\
\text { (Ln } A_{S-1} \text { ) }\end{array}$ & & & $\begin{array}{l}0.0003 \\
(4.37)\end{array}$ & \\
\hline $\begin{array}{l}\text { New hires } \\
\quad\left(\text { Ln Hire }{ }_{i t}\right)\end{array}$ & & & & $\begin{array}{l}0.001 \\
(0.11)\end{array}$ \\
\hline $\begin{array}{l}\text { Separations } \\
\quad\left(\text { Ln Sep }_{i t}\right)\end{array}$ & & & & $\begin{array}{l}-0.015 \\
(0.89)\end{array}$ \\
\hline$R^{2}$ & 0.9913 & 0.9897 & 0.9896 & 0.9906 \\
\hline $\operatorname{Ln} L$ & 381.168 & 353.86 & 352.4115 & 377.6213 \\
\hline$N$ & 337 & 337 & 327 & 327 \\
\hline
\end{tabular}

* Unstandardized coefficients are reported, with associated $t$-statistics shown in parentheses. $\operatorname{Ln} L$ is the natural logarithm of the likelihood function.

${ }^{\text {a }}$ Significantly different from one $(p<0.000001)$.

${ }^{\mathrm{b}}$ Significantly different from one $(p<0.001)$.

${ }^{c}$ Significantly different from one $(p<0.05)$.

summed across all yards, should be positive and significant. As can be seen from Column (1) or Table 2, this variable has a negative coefficient. This negative coefficient does not support the hypothesis of a transfer of learning. Similarly, when lagged cumulative output summed across all yards is included as an explanatory variable, it has a negative coefficient (results available on request).

Column (2) of Table 2 presents the results of our test of the hypothesis that yards with later start dates are more productive than yards with earlier start dates. The model in Column (2) was estimated without dummy variables for shipyards. Since the start dates can be written as a linear combination of the yard dummies, the coefficients would not be identified if the start dates and the yard dummies were both included. ${ }^{11}$ The significant

11 The equation in Column (2) of Table 2 is nested in Column (1) of Table 1. Because the equation in Column (1) of Table 1 has dummy variables (not shown in the table) that capture differences in productivity across yards due to differences in start dates as well as other yard-specific effects, the lower $R^{2}$ in Column (2) of Table 2, compared to that of Column (1) of Table 1, is to be expected. 
positive coefficient on variable $S$, the start date, in Column (2) of Table 2 suggests that yards with later start dates were more productive than yards with early start dates.

We also included cumulative output in all yards prior to start date as an explanatory variable to capture knowledge potentially available to each yard at the date it began production (see Column (3)). The variable also has a significant positive coefficient, indicating that when yards began production they benefited from production up to that date at other yards. ${ }^{12}$

Finally, we estimated a model that included all variables of interest. The start dates and aggregate cumulative output prior to the start dates could not be included in this model since these variables are perfectly correlated with the shipyard dummy variables. These results, which are presented in Column (4) of Table 2, are very similar to those reported earlier. The knowledge variable is positive and highly significant, and the depreciation parameter is significantly less than one. Thus, these results provide further evidence that knowledge acquired through production depreciates rapidly.

\section{Robustness of the Results}

In this section, we explore other potential explanations of our findings. Costs of changing the rate of output are often emphasized in discussions of production activities (e.g., Asher 1956). For example, Lockheed executives frequently mentioned the difficulties encountered when they increased the rate of production of the L-1011 (Wall Street Journal, 1980 b, p. 19). We investigated the importance of adjustment costs in our data by including variables measuring the rate of change in input levels from one period to the next. While there is evidence that adjustment costs may be present in the Liberty Ship program, our results on the persistence and transfer of learning (available on request) are unchanged by the inclusion of the adjustment-cost variables.

We also investigated whether different results would be obtained with a more general specification of the production function. The analyses presented in Tables 1 and $2 \mathrm{em}$ ployed the Cobb-Douglas specification. We performed additional analyses using the more general translog specification (Berndt and Christensen 1973). The translog model introduces $(\operatorname{Ln} H)^{2},(\operatorname{Ln} W)^{2}$, and $\operatorname{Ln} H \operatorname{Ln} W$ in addition to the terms appearing in the CobbDouglas production function. We estimated the translog for all versions of the model in Tables 1 and 2. In all cases except Column (2) of Table 1, the additional terms introduced for the translog are significant $(p<0.05)$. Estimates for $\lambda$ in these alternative equations range from 0.62 to 0.80 and are all significantly less than one. Moreover, the coefficient estimate of the calendar time variable (which was negative and significant in Column (4) of Table 1) is smaller in magnitude and not significant in the translog model. Thus, the results with the more general translog model reinforce and amplify the results on transfer, persistence, and turnover reported earlier.

Use of cumulative output, the conventional measure of learning, in logarithmic form as in equation (1) implies that unit cost converges to zero as cumulative output increases. It may be that cumulative output is the correct measure of learning but that unit cost converges to a positive number rather than to zero. To investigate this possibility, we estimated Cobb-Douglas and translog production functions with both $\operatorname{Ln} K$ and $(\operatorname{Ln} K)^{2}$ as predictors. This quadratic function, evaluated at values of $K$ less than the value at which the function reaches a minimum, can approximate a function with a positive asymptote-even with no depreciation of learning. The maximum likelihood estimate of $\lambda$ was significantly less than one when learning was included as a quadratic function.

\footnotetext{
${ }^{12}$ This is the one issue on which our analyses of annual and monthly data differ. In the analysis of annual data, there is no evidence that yards with later start dates were more productive initially than yards with early start dates. Data disaggregated to monthly observations permit more precise measurement of the effects of start date than the annual data do. Hence, in this one instance of a difference between the annual and monthly analyses we are inclined to think that the results of the monthly analysis are more informative.
} 


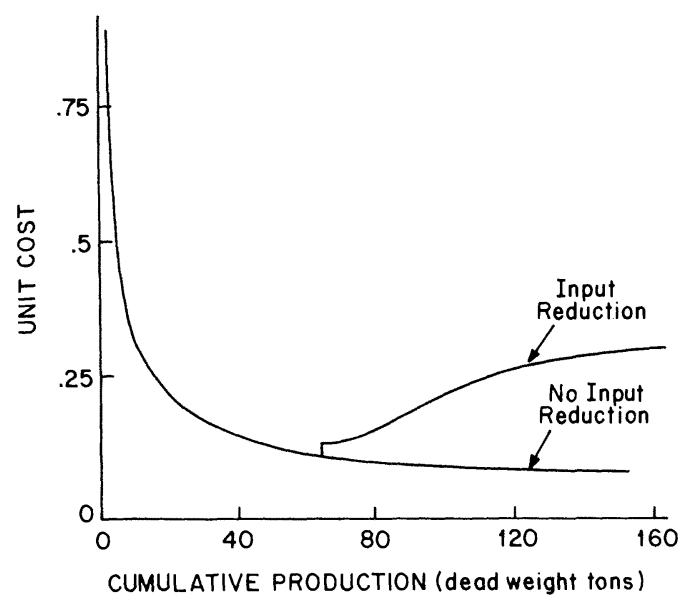

FIGURE 1. The Relationship Between Unit Costs and Cumulative Production When Inputs Are Reduced to Half Their Initial Levels.

This provides further evidence that knowledge acquired through learning by doing depreciates rapidly (results available upon request).

All of the results reported here were obtained by use of ordinary least squares. Since there may be simultaneity in the choice of inputs and outputs, we estimated several of the equations using the nonlinear two-stage least-squares procedure of Amemiya (1974). The results were virtually identical to those obtained using ordinary least squares. ${ }^{13}$

The results consistently exhibit evidence of economies of scale in shipbuilding. For example, the results in Column (1) of Table 1 indicate that an increase in hours and shipways of one percent would result in a 1.31 percent increase in output, other things constant. ${ }^{14}$ The knowledge variable, $K$, is highly significant when measures of labor hours and shipways are included in the models. Thus, the results indicate that when input effects and economies-of-scale effects are controlled for, there is strong evidence of learning.

Figure 1 illustrates the effects of economies of scale and depreciation on unit costs. In this simulation, input levels were held constant at the sample mean for the first 13 months of yard operation. The levels of inputs were halved in month 14 and held constant thereafter. The reduction in inputs caused an immediate increase in unit costs, indicated by the vertical line at the date of the reduction. This increase in unit costs is due to scale economies: the reduction in inputs results in a more than proportionate reduction in output. The increase in costs thereafter is due to the depreciation of knowledge. The reduction in inputs led to a reduction in output. This reduction in output then reduced the knowledge variable, $K$, because the gains in knowledge from current production were not sufficient to offset the losses in knowledge from depreciation of the previous period's stock. If inputs were held constant indefinitely at their new level, the stock of knowledge would eventually decline to a level sustained by production.

Finally, to test the generalizability of our results, especially to modern production environments, we obtained data for the production of an advanced jet produced in the 1970s and 1980s. Since these data were from a single firm, we were able to examine

\footnotetext{
${ }^{13}$ As instruments, we used current and lagged values of real wages, shipyard dummy variables, time and time squared, lagged endogenous variables (output, shipways, labor hours) and current and lagged exogenous variables. An appendix that explains the logic underlying our choice of instruments and presents the NL2SLS estimation results is available on request.

${ }^{14}$ The results indicate that an increase in shipways would result in a more than proportionate increase in output, other things constant. One would expect that the incremental gains from adding shipways would diminish if a large number of additional shipways were added. Our results, including those with the translog production function, indicate that the yards did not add a sufficient number of shipways for this diminution to be encountered.
} 
persistence but not transfer. We found evidence of depreciation of knowledge in the production of the advanced jet. Thus, there is evidence that the results on persistence generalize to other production environments.

\section{Application of Persistence Results}

In this section, we apply our results on persistence to Lockheed's production of the L1011 and suggest a possible explanation for the limited learning benefits Lockheed experienced. Our results on persistence indicate that cost forecasts based on cumulative output are likely to contain large errors for production programs in which there are variations in the rate of output over time. The production of the L-1011 TriStar was characterized by wide variations in the rate of output. Lockheed produced 17 planes in 1972, 39 in 1973, and 41 in 1974 (Lockheed Annual Report, 1972, p. 1; 1974, p. 8). Production dropped to 25 in 1975 (Wall Street Journal, 1976, p. 2), to 16 in 1976 (Wall Street Journal, 1977, p. 11), and to 6 in 1977 (Aviation Week and Space Technology, 1979, p. 32). Eight planes were produced in 1978 (Wall Street Journal, 1980b, p. 19). The rate of production was then increased to 25 per year until February 1981 when production was reduced to 18 per year (Wall Street Journal, 1981a, p. 10). Additional reductions to 12 or fewer per year were scheduled (Wall Street Journal, 1981 c, pp. 1, 22) and plans to phase out production of the plane were announced on December 7, 1981 (Wall Street Journal, 1981b, p. 3).

For a wide range of values of the depreciation parameter, $\lambda$, in equation (2), Lockheed's production rates imply that the knowledge variable for the L-1011 peaked in late 1974 or early 1975 and then declined. A high value of the knowledge variable implies, of course, a low level of production costs. Based on these observations and on the hypothesis that Lockheed experienced depreciation of knowledge, we examined published reports to determine whether Lockheed's costs were relatively low in 1974 and 1975, and whether those costs rose subsequently as rates of production were reduced.

Lockheed estimated in 1973 that it would reach the point where production costs fell below price in mid-1974 (Wall Street Journal, 1974, p. 1). In November 1975, Lockheed reported that production costs were, in fact, less than the price at which each plane was being sold (Wall Street Journal, 1975, p. 1). Thus, it appears that production costs were below price during the period in which the knowledge variable $K$ would have been highest if a depreciation parameter value on the order of that estimated in this paper is used. Cuts in production occurred in late 1975, and costs rose to exceed price-a situation that apparently persisted for the remainder of the production program (Wall Street Journal, 1980a, p. 12). The price at which the L-1011 sold increased more rapidly than inflation during this period, but production costs increased even more rapidly. ${ }^{15}$

A detailed analysis of L-1011 data would be required to test the hypothesis that depreciation of knowledge occurred. For example, it would be necessary to determine that the increase in costs that occurred when production was reduced was not due to scale economies, to the inclusion of overhead on fixed capital in the calculation of variable production costs, to changing wage rates, ${ }^{16}$ or to adjustment costs. The pattern of costs reported by Lockheed, however, is consistent with the depreciation hypothesis. Given the huge sums of money lost by Lockheed on the TriStar program, averaging more than

\footnotetext{
${ }^{15}$ The price planes were sold for in 1975 was $\$ 20$ million. Adjusted for inflation using the producer price index, this is equivalent to a price in 1968 dollars of $\$ 12.58$ million. In 1982, the L-1011 was sold for more than $\$ 50$ million per plane. The corresponding price in 1968 dollars is $\$ 18$ million. Thus, in 1975 , production cost per plane was less than $\$ 12.58$ million in real terms while in 1982 , production cost was greater than $\$ 18$ million in real terms.

${ }^{16}$ This problem does not arise in our analysis of the Liberty Ship program because we use physical units of inputs and output rather than dollar values.
} 
\$125 million per year over the decade ending in 1980 (Business Week, 1980, p. 88), improved strategies for forecasting costs are clearly of great importance.

Reinhardt (1973) criticized Lockheed's analysis of the L-1011 program for omitting the opportunity cost of nonrecurring expenses for developing technology and production facilities for the L-1011. In his forecast of recurring production costs, Reinhardt used cumulative production as the measure of learning and arrived at a conclusion similar to Lockheed's: production costs would be below price at about the 50th plane. Our results on depreciation suggest that production costs would rise if the rate of production fell. Thus, it appears that allowing for depreciation of knowledge would have led to even more pessimistic forecasts than Reinhardt's analysis indicated.

\section{Conclusion}

Our results on persistence indicate that knowledge acquired in production depreciates rapidly. The conventional measure of learning, cumulative output, significantly overstates the persistence of learning. Controlling for labor turnover does not alter this conclusion.

These results on the lack of persistence of organizational learning are consistent with results in psychology on the lack of persistence of individual learning. Further, the results on the insignificance of turnover are consistent with the persistence results. Knowledge depreciates very rapidly-much more rapidly than the rate of labor turnover.

Concerning transfer, our results indicate that shipyards beginning production later in the war were more productive than yards with early start dates. The initial gain in productivity may have been due to learning by doing in the design and construction of shipyards and the equipment used in them as well as to learning by doing in the construction of ships. Once shipyards began production they did not benefit from learning at other yards.

Why knowledge depreciates is an interesting question for future research. Theoretically, knowledge could depreciate because individuals forget how to perform their tasks or because individuals leave and are replaced by others with less experience. While there is no evidence that turnover contributed to depreciation in the Liberty Ship environment, it might matter in other organizational contexts. The jobs of production workers in the Liberty Ship program were highly standardized and designed to be low in skill requirements (Lane 1951). Turnover might matter more in contexts where employees are highly skilled and jobs are less standardized.

Depreciation could also be due to technological obsolescence. This might occur, for example, if a part is redesigned and new techniques must be learned to manufacture it. Technological obsolescence could also be due to process changes that make old skills obsolete.

Depreciation might also result from lost or inadequate organizational records. An interesting example of lost records occurred at the Steinway piano company. ${ }^{17}$ Lenehan (1982) describes the difficulty Steinway had putting a discontinued piano, for which the company did not have any records, back into production.

The Steinway example illustrates how knowledge can depreciate when production is discontinued. Steinway's efforts to put the discontinued piano back into production also illustrate where and how knowledge can be embedded in organizations. An engineer at Steinway's New York plant, who had one of the models at home, took it apart and made drawings from the existing piano. He also located records at Steinway's Hamburg factory. In addition, the engineer tracked down an old foreman who loaned him his "black book," which contained very valuable information about how to make the piano. This example is consistent with theoretical treatments of organizational learning which suggest that knowledge can, to some extent, be embedded in individual employees, in the structure

\footnotetext{
${ }^{17}$ We are grateful to one of the referees and the Associate Editor for suggesting this very interesting example.
} 
and culture of the organization and its records and routines, and in the organization's products and technology (e.g., see Hirsch 1952; Hayes and Wheelwright 1984; Levitt and March 1988).

While our results do not enable us to identify directly where knowledge was embedded in the Liberty Ship organizations, they suggest that certain factors were not prime sources. For example, the insignificance of the turnover variable suggests that the departure of direct production workers was not a prime determinant of depreciation. The initial gain in productivity experienced by shipyards beginning production later in the war may suggest that part of the knowledge acquired in the Liberty Ship program was embedded in technology. The results indicating rapid depreciation within shipyards, however, suggest that learning was not totally embedded in technology, since if it were, we should not see such rapid declines in productivity. Further support for this conclusion is provided by the finding that yard-specific production history was highly significant in explaining shipbuilding productivity, but neither time nor aggregate cumulative output was positively associated with productivity improvements. An interesting hypothesis, which is consistent with the results, is that learning was embedded in the various organizations-in their standard operating procedures, methods of communication and coordination, and shared understandings about how work is to be done (cf. March and Simon 1958; Levitt and March 1988).

If our result on depreciation turns out to be a fundamental feature of learning by doing, it has important strategic implications. A strategy of adopting high output levels during initial periods of production followed by relatively lower rates of output may be an effective way to increase productivity if learning is related to cumulative output (cf. Conley 1970), but is not necessarily preferable to a policy of relatively uniform production through time if learning is tied only to recent output. Further, in industries where learning does not persist, a firm with relatively low cumulative output such as a recent entrant to an industry need not be at a competitive disadvantage if its recent output levels are comparable to those of its rivals.

The results on depreciation also have important implications for forecasting production costs. Failure to allow for depreciation may result in forecasts with systematic errors. This is particularly likely to occur when a conventional learning curve based on cumulative output is estimated from a past production program and then used to forecast costs on a future program. If depreciation occurs and if the rate of output on the past program differs from that expected for the planned program, then the cost forecasts will contain systematic errors.

In closing, our results suggest that there is a substantial component of organizational learning that depreciates rapidly. Our results also provide evidence of a type of transfer: organizations beginning production later are more productive than those with early start dates. Once organizations begin production, however, they do not appear to benefit from learning at other organizations. It will be important to undertake further empirical research to determine the conditions under which our results concerning the persistence and transfer of learning hold. It will also be important to identify factors affecting the rate of learning and "forgetting" in organizations. ${ }^{18}$

\footnotetext{
${ }^{18}$ This material is based upon work supported by the National Science Foundation under Grants RII-840991 and SES-8808711 and by the Center for Teaching and Research in Integrated Manufacturing Systems at Stanford University. Parts of the project were completed while the first author was a Visiting Assistant Professor and the second author was a Doctoral Candidate in the Department of Industrial Engineering and Engineering Management at Stanford University and the third author was a National Fellow at the Hoover Institution, Stanford University. The work has been presented at Carnegie Mellon University, Duke University, the University of Illinois, the University of Michigan, the University of Virginia, Stanford University, the 1987 ORSA/TIMS Meeting in St. Louis, and the 1987 Conference on Current Issues in Productivity at Rutgers University. The authors wish to thank participants in these forums, the reviewers, and Rukmini Devadas, Paul Goodman, Howard Gruenspecht, Paul Joskow, Robert Kaplan, Daniel Levinthal, Marvin Lieberman, John Muth, and Gerald Salancik for their very helpful comments.
} 


\section{References}

Alchian, A., "Reliability of Progress Curves in Air-frame Production,” Econometrica, 31 (1963), 679-693.

AMEMIYA, T., "The Nonlinear Two-stage Least-squares Estimator," J. Econometrics, 2 (1974), 105-110.

ANDERSOn, J. R., Cognitive Psychology and Its Implications (2nd ed.), W. H. Freeman and Company, New York, 1985.

ANZAI, Y. AND H. A. Simon, "The Theory of Learning by Doing," Psychological Rev., 86 (1979), 124-140.

ASHER, H., Cost-Quantity Relationships in The Air-frame Industry, Rand Corporation, Santa Monica, CA, 1956.

Aviation Week \& Space Technology, "TriStar Production Costs Offset Lockheed Profits," (October 15, 1979), 32.

BALOFF, N., "Estimating the Parameters of The Startup Model-An Empirical Approach," J. Industrial Engineering, 18 (1967), 248-253.

_. "Startup Management," IEEE Trans., EM-17 (1970), 132-141.

Batchelder, C. A., H. E. Boren, H. G. Campbell, J. A. Dei Rossi And J. P. Large, An Introduction to Equipment Cost Estimating, Rand Corporation, Santa Monica, CA, 1969.

BERNDT, E. R. AND L. R. CHRISTENSEN, "The Translog Function and The Substitution of Equipment, Structures, and Labor in U.S. Manufacturing 1929-68," J. Econometrics, 1 (1973), 81-113.

Business Week, "The TriStar's Trail of Red Ink," (July 28, 1980), 88.

CONLEY, P., "Experience Curves as a Planning Tool," IEEE Spectrum, 7 (1970), 63-68.

Dhrymes, P. J., "On the Treatment of Certain Recurrent Nonlinearities in Regression Analysis," Southern Economic J., 23 (1966), 187-196.

Ebbinghaus, H., Memory: A Contribution to Experimental Psychology (Transl. by Henry A. Ruger and Clara E. Bussenius and with an introduction by Ernest Hilgard, 1964), Dover, New York, 1885.

Fisher, G. J., A Statistical Summary of Shipbuilding Under the U.S. Maritime Commission During World War II, Historical Reports of War Administration, United States Maritime Commission, 1949.

GoldFeld, S. M. AND R. E. QuANDT, Nonlinear Methods in Econometrics, North-Holland, Amsterdam, 1972.

GRAHAM, C. H. AND R. M. GAGNE, "The Acquisition, Extinction, and Spontaneous Recovery of A Conditioned Operant Response,” J. Experimental Psychology, 26 (1940), 251-280.

GuetzKow, H. AND H. A. Simon, "The Impact of Certain Communication Nets upon Organization and Performance in Task-oriented Groups," Management Sci., 1 (1954), 233-250.

HAYES, R. H. AND S. C. WhEELWRIGHT, Restoring our Competitive Edge: Competing through Manufacturing, Wiley, New York, 1984.

Hirsch, W. Z., "Manufacturing Progress Functions,” Rev. Economics and Statist., 34 (1952), 143-155.

-, "Firm Progress Ratios," Econometrica, 24 (1956), 136-143.

JOSKOw, P. L. AND N. L. RosE, "The Effects of Technological Change, Experience, and Environmental Regulation on the Construction Cost of Coal-burning Generating Units," Rand J. Economics, 16 (1985), 1-27.

JUCKER, J. V., "The Transfer of Domestic-Market Production to a Foreign Site," AIIE Trans., 9 (1977), 321329.

Kelsey, S. F., S. M. Mullin, K. M. Detre, H. Mrtchell, M. J. Cowley, A. R. Gruentzig And K. M. KENT, "Effect of Investigator Experience on Percutaneous Transluminal Coronary Angioplasty," Amer. J. Cardiology, 53 (1984), 56C-64C.

KILBRIDGE, M., “A Model for Industrial Learning Costs,” Management Sci., 8 (1962), 516-527.

Kolers, P. A., "Reading a Year Later,” J. Experimental Psychology: Human Learning and Memory, 2 (1976), 554-565.

LANE, F. C., Ships for Victory: A History of Shipbuilding under the U.S. Maritime Commission in World War II, The Johns Hopkins Press, Baltimore, 1951.

LeavitT, H. J., "Some Effects of Certain Communication Patterns on Group Performance," J. Abnormal and Social Psychology, 46 (1951), 38-50.

LENEHAN, M., “The Quality of the Instrument,” The Atlantic Monthly, 250 (1982), 32-58.

LEVITT, B. AND J. G. MARCH, “Organizational Learning,” Ann. Rev. Sociology, 14 (1988), 319-340.

LeVy, F. K., “Adaptation in the Production Process,” Management Sci., 11 (1965), B136-B151.

Lieberman, M. B., "The Learning Curve and Pricing in the Chemical Processing Industries," Rand J. Economics, 15 (1984), 213-228.

LOCKHEED AIrCRAFT CORPORATION, Lockheed Annual Report, Corporate Publications, Burbank, CA 1972. , Lockheed Annual Report, Corporate Publications, Burbank, CA 1974.

MarCh, J. G. AND H. A. Simon, Organizations, Wiley, New York, 1958.

Mazur, J. E. AND R. HASTIE, "Learning as Accumulation: A Reexamination of The Learning Curve," Psychological Bulletin, 85 (1978), 1256-1274.

Newell, A. AND P. S. Rosenbloom, "Mechanisms of Skill Acquisition and the Law of Practice," In J. R. Anderson (Ed.), Cognitive Skills and their Acquisition, Lawrence Erlbaum, Hillsdale, NJ, 1981, 1-55.

Preston, L. E. AND E. C. Keachie, "Cost Functions and Progress Functions: An Integration," Am. Economic Rev., 54 (1964), 100-107. 
RAPPING, L., “Learning and World War II Production Functions,” Rev. Economics and Statist., 47 (1965), $81-$ 86.

REINHARDT, U. E., "Break-Even Analysis for Lockheed's Tri Star: An Application of Financial Theory," $J$. Finance, (1973), 821-838.

SHESHINSKI, E., "Tests of the Learning by Doing Hypothesis," Rev. Economics and Statist., 49 (1967), 568578.

SMunt, T. L., "The Impact of Worker Forgetting on Production Scheduling," Internat. J. Production Res., 25 (1987), 689-701.

AND T. E. MORTON, "The Effect of Learning on Optimal Lot Sizes: Further Developments on the Single Product Case," IIE Trans., 17 (1985), 33-37.

SPENCE, A. M., "The Learning Curve and Competition," Bell J. Economics, 12 (1981), 49-70.

SulE, D. R., "Effect of Learning and Forgetting on Economic Lot Size Scheduling Problem," Internat. J. Production Res., 21 (1983), 771-786.

Thorndike, E. L., "Animal Intelligence: An Experimental Study of The Associative Processes in Animals," The Psychological Rev.: Ser. Monograph Supplements, 2 (1898), 1-109.

Thurstone, L. L., "The Learning Curve Equation," Psychological Monographs, 26 (1919), 1-51.

Wall Street Journal, "Lockheed is Planning a Write-down of $\$ 600$ Million on Its TriStar in a Complex Financial Restructuring," (June 3, 1974), 1.

, "Lockheed Net Soared 108\% in 3rd Period but Outlook for TriStar Sales is Dismal," (November 7, 1975), 1.

, “Lockheed Plans L-1011 Charges of \$515 million,” (March 31, 1976), 2.

, "Lockheed Is Trying to Interest Airlines in Shorter-range Version of L-1011 Jet," (March 16, 1977), 11.

, “Lockheed Loses Hope TriStar Program Will Show Profit but Sees Improvement," (May 14, 1980a), 12.

, "Lockheed Losses on TriStar Grew in 2nd Quarter," (June 20, 1980b), 19.

, "Lockheed to Cut L-1011 Production by Fall, Fueling Speculation on Plane's Survival," (July 1, 1981a), 10.

, “Lockheed Plans to End Output of L-1011 Jet," (December 8, 1981b), 3.

, "Delayed Takeoff: Stalled Jetliner Makers May Not Rise Steeply Even If the Airlines Do." (December 9, 1981c), 1, 22.

WiCKelgren, W. A., "Memory Storage Dynamics," In W. K. Estes (Ed.), Handbook of Learning and Cognitive Processes. 4, Lawrence Erlbaum Associates, Hillsdale, NJ, 1976, 321-361.

Womer, N. K., "Learning Curves, Production Rate, and Program Costs," Management Sci., 25 (1979), 312319.

—, "Estimating Learning Curves from Aggregate Monthly Data," Management Sci., 30 (1984), 982-992.

Wright, T. P., "Factors Affecting the Costs of Airplanes," J. Aeronautical Sci., 3 (1936), 122-128.

YElle, L. E., "The Learning Curve: Historical Review and Comprehensive Survey," Decision Sci., 10 (1979), 302-328.

Zimmerman, M. B., "Learning Effects and the Commercialization of New Energy Technologies: The Case of Nuclear Power," Bell J. Economics, 13 (1982), 297-310. 
http://www.jstor.org

\title{
LINKED CITATIONS \\ - Page 1 of 1 -
}

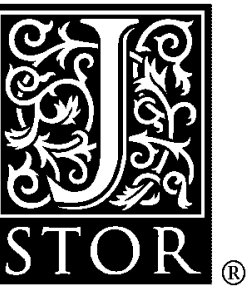

You have printed the following article:

The Persistence and Transfer of Learning in Industrial Settings

Linda Argote; Sara L. Beckman; Dennis Epple

Management Science, Vol. 36, No. 2. (Feb., 1990), pp. 140-154.

Stable URL:

http://links.jstor.org/sici?sici=0025-1909\%28199002\%2936\%3A2\%3C140\%3ATPATOL\%3E2.0.CO\%3B2-0

This article references the following linked citations. If you are trying to access articles from an off-campus location, you may be required to first logon via your library web site to access JSTOR. Please visit your library's website or contact a librarian to learn about options for remote access to JSTOR.

\section{References}

\section{Reliability of Progress Curves in Airframe Production}

Armen Alchian

Econometrica, Vol. 31, No. 4. (Oct., 1963), pp. 679-693.

Stable URL:

http://links.jstor.org/sici?sici=0012-9682\%28196310\%2931\%3A4\%3C679\%3AROPCIA\%3E2.0.CO\%3B2-V

\section{Firm Progress Ratios}

Werner Z. Hirsch

Econometrica, Vol. 24, No. 2. (Apr., 1956), pp. 136-143.

Stable URL:

http://links.jstor.org/sici?sici=0012-9682\%28195604\%2924\%3A2\%3C136\%3AFPR\%3E2.0.CO\%3B2-6

\author{
Break-Even Analysis for Lockheed's Tri Star: An Application of Financial Theory \\ U. E. Reinhardt \\ The Journal of Finance, Vol. 28, No. 4. (Sep., 1973), pp. 821-838. \\ Stable URL: \\ http://links.jstor.org/sici?sici=0022-1082\%28197309\%2928\%3A4\%3C821\%3ABAFLTS\%3E2.0.CO\%3B2-Q
}

